\title{
FIRST SURVEY OF FRUIT FLY (DIPTERA: TEPHRITIDAE) AND PARASITOID DIVERSITY AMONG MYRTACEAE FRUIT ACROSS THE STATE OF BAHIA, BRAZIL ${ }^{1}$
}

\author{
LIDIA NOGUEIRA SILVA² MÍRIAN SILVA SANTOS ${ }^{3}$, VIVIAN SIQUEIRA DUTRA ${ }^{4}$, \\ ELTON LUCIO ARAUJO ${ }^{5}$, MARCO ANTONIO COSTA ${ }^{6}$, JANISETE GOMES SILVA ${ }^{7}$
}

ABSTRACT - The objective of this study was to evaluate the diversity of fruit fly (Diptera: Tephritidae) species that use myrtaceous fruit, particularly guava, as hosts in several localities in the state of Bahia and to determine the infestation rates, pupal viability rates, and fruit fly-parasitoid associations. Sampling of myrtaceous fruit was carried out in 24 municipalities in different regions in the state of Bahia. Four fruit fly species, Anastrepha fraterculus, Anastrepha zenildae, Anastrepha sororcula, and Ceratitis capitata were obtained from the collected fruit. Three parasitoid species (Hymenoptera: Braconidae) emerged from Anastrepha larvae/pupae, Doryctobracon areolatus, Utetes anastrephae, and Asobara anastrephae. Doryctobracon areolatus emerged from A. fraterculus, A. sororcula and A. zenildae; Utetes anastrephae emerged from A. fraterculus and A. zenildae; and Asobara anastrephae emerged from A. fraterculus. Fruit fly and myrtaceous fruit associations are reported for the first time in several municipalities in the state of Bahia. A. zenildae was found infesting Syzygium malaccense for the first time in Brazil.

Index terms: fruit flies, tephritids, braconids, parasitism, Anastrepha, Ceratitis.

\section{PRIMEIRO LEVANTAMENTO DE MOSCA DAS FRUTAS (DIPTERA: TEPHRITIDAE) E DIVERSIDADE DE PARASITOIDES ENTRE FRUTOS DE MYRTACEAE EM TODO O ESTADO DA BAHIA, BRASIL}

RESUMO - O objetivo deste estudo foi avaliar a diversidade de espécies de moscas-das-frutas (Diptera: Tephritidae) que usam frutos de mirtáceas, particularmente goiaba, como hospedeiro em várias localidades do Estado da Bahia e determinar os índices de infestação, taxa de viabilidade pupal e associações entre plantas hospedeiras, moscas-das-frutas e parasitoides. Coletas de frutos de mirtáceas foram realizadas em 24 municípios, em diferentes regiões do Estado da Bahia. Quatro espécies de moscas-das-frutas, Anastrepha fraterculus, Anastrepha zenildae, Anastrepha sororcula e Ceratitis capitata, foram obtidas dos frutos coletados. Três espécies de parasitoides (Hymenoptera: Braconidae) emergiram das larvas e pupas de Anastrepha, Doryctobracon areolatus, Utetes anastrephae e Asobara anastrephae. Doryctobracon areolatus emergiu de A. fraterculus, A. sororcula e A. zenildae; Utetes anastrephae emergiu de A. fraterculus e $A$. zenildae; e Asobara anastrephae emergiu de A. fraterculus. Associações entre moscas-das-frutas e mirtáceas são relatadas pela primeira vez em vários municípios do Estado da Bahia. A. zenildae foi registrada infestando Syzygium malaccense pela primeira vez no Brasil.

Termos para Indexação: moscas-das-frutas, tefritídeos, braconídeos, parasitismo, Anastrepha, Ceratitis.

\footnotetext{
'(Trabalho 195-10). Recebido em: 30-08-2010. Aceito para publicação em: 23-03-2011.

${ }^{2}$ Mestre em Genética, Universidade Estadual de Santa Cruz. Ilhéus, Bahia, Brazil; lidia.nogueira@yahoo.com.br

${ }^{3}$ Mestre em Zoologia, Universidade Estadual de Santa Cruz. Ilhéus, Bahia, Brazil; agro.mirian@gmail.com

${ }^{4}$ Mestre em Zoologia, Universidade Estadual de Santa Cruz. Ilhéus, Bahia, Brazil. Current: Instituto Nacional de Pesquisas da Amazônia, Manaus, Amazonas, Brazil; vdbiologia@yahoo.com.br,

${ }^{5}$ Doutor em Entomologia, Universidade Federal Rural do Semi-Árido, Mossoró, Rio Grande do Norte, Brazil, elton@ufersa.edu.br ${ }^{6}$ Doutor em Genética e Evolução, Universidade Estadual de Santa Cruz. Ilhéus, Bahia, Brazil; costama@uesc.br,

${ }^{7}$ Doutora em Ciências Biológicas (Biologia/Genética), Universidade Estadual de Santa Cruz. Ilhéus, Bahia, Brazil; jgs10@uol.com.br
} 


\section{INTRODUCTION}

Fruit flies (Diptera: Tephritidae) have a serious impact on fruit production worldwide due to both their direct economic impact (i.e. fruit damage caused by larval feeding) and strict quarantine restrictions imposed by several countries (ALUJA;MANGAN, 2008). These insects are among the most important agricultural pests in Brazil whose fresh fruit production is estimated at 43 million tons yearly (IBRAF, 2007). Brazil harbors a high diversity of fruit flies that infest a wide range of hosts in 54 plant families and the species of economic importance are restricted to some species in the genus Anastrepha (Schiner) and one introduced species, Ceratitis capitata (Wiedemann) (ZUCCHI, 2007).

Myrtaceae is one of the most diverse plant families in Brazil with about 1,000 species. It is a well-represented family in the Atlantic Forest and comprises several commercially important species such as Psidium guajava L. (guava) and Eugenia uniflora L. (Surinam cherry) (GRESSLER et al., 2006). Brazil is the world's largest guava producer, and more than $50 \%$ of its total guava cultivated area is in the northeastern region, mainly in the states of Pernambuco and Bahia (MAPA, 2002; LIMA et al., 2008).

Several Anastrepha species infest myrtaceous fruit, and the genera Psidium, Eugenia, and Syzygium are some of the most important hosts. It is noteworthy that guava is infested by the highest diversity of fruit flies in Brazil, C. capitata and 11 species of Anastrepha (RAGA et al., 2006; ZUCCHI, 2007; SOUZA FILHO et al., 2009).

Fruit flies are considered key insect pests for fresh fruit production in Brazil. Although there has been an increase in fruit production in the state of Bahia, studies on fruit fly host associations, infestation levels, and natural enemies statewide are still scant. Most studies previously carried out in Bahia focused on a single location through fruit collection (SOUZA-FILHO et al., 2007; SILVA et al., 2008) or using traps (NASCIMENTO; ZUCCHI, 1981; DUTRA et al., 2009).

In the present study, we carried out fruit collections in several localities in the state of Bahia to evaluate the diversity of fruit fly species that use myrtaceous fruit, particularly guava, as hosts. Moreover, the infestation rates, pupal viability rates, and fruit fly-parasitoid associations were also determined. Fruit fly and myrtaceous fruit associations in several municipalities in the state of Bahia are reported for the first time.

\section{MATERIAL AND METHODS}

Sampling of myrtaceous fruit was carried out in 24 municipalities across different regions in the state of Bahia from April 2006 to April 2007. Samples of ripe or ripening fruit were collected randomly both from unsprayed tree canopies and fallen fruit at the ground level and brought to the Laboratório de Entomologia of Universidade Estadual de Santa Cruz (UESC), Ilhéus, Bahia, Brazil. The collected fruit were counted, weighed, and individually placed in plastic containers with a layer of vermiculite and covered with voile cloth to avoid reinfestation. All puparia obtained were placed in $30 \mathrm{~mL}$ plastic containers with a layer of vermiculite at the bottom and covered with voile cloth until adults emerged.

Fruit flies were identified based on the keys provided by Zucchi (2000) and Araujo and Zucchi (2006). Braconid parasitoids were identified based on the keys by Canal and Zucchi (2000). Voucher specimens were deposited at the Laboratório de Entomologia, UESC.

Infestation values reported in this study were based on the number of fruit fly larvae per $\mathrm{Kg}$ of fruit and on the number of fruit fly larvae per number of fruit according to Nascimento et al. (2000).

\section{RESULTS AND DISCUSSION}

A total of 857 fruit that represented five myrtaceous species and weighed $55.68 \mathrm{Kg}$ were collected. From those fruit, 2,134 puparia were recovered. Of these puparia, a total of 1,263 fruit fly adults (628 males and 630 females) emerged with a pupal viability of $59.2 \%$.

Four fruit fly species were recovered from the collected fruit, Anastrepha fraterculus (Wiedemann) (67.5\%), Anastrepha zenildae Zucchi (15.1\%), Anastrepha sororcula Zucchi (9.1\%), and C. capitata $(8.3 \%)$ (Table 1).

Infestation by $C$. capitata and Anastrepha spp. was detected in native fruit such as guava and Psidium guineense Swart. N (Brazilian guava), whereas the introduced host Syzygium malaccense (L.) Merr. \& L.M. Perry (Malay apple) was infested solely by Anastrepha species (Table 1).

In the Recôncavo region, we found three Anastrepha species infesting myrtaceous fruit, $A$. fraterculus $(68.9 \%), A$. sororcula $(17.8 \%)$, and $A$. zenildae (13.3\%). Nascimento and Zucchi (1981) carried out a fruit fly survey in this region using traps and reported that the most frequent species 
were A. fraterculus, Anastrepha obliqua (Macquart), A. sororcula, Anastrepha distincta Greene, and Anastrepha serpentina (Wiedemann). It was report the occurrence of $A$. zenildae in this region for the first time. Guava fruit hosted three Anastrepha species, A. fraterculus, $A$. sororcula, and $A$. zenildae, whereas the other two hosts collected in the region, Myrciaria cauliflora (Mart.) O.Berg. (jaboticaba) and Surinam cherry, were infested only by $A$. fraterculus. This is the first record of $A$. fraterculus infesting jaboticaba in Bahia (Table 1). Malavasi et al. (1980) reported $A$. fraterculus, A. serpentina, A. pickeli Lima, 1934 and A. obliqua in Conceição do Almeida and $A$. antunesi Lima in Santo Amaro da Purificação; however, they provided no specific information regarding fruit flyhost associations in this region.

In the southern region, A. fraterculus (77.6\%), A. sororcula (6.0\%), and A. zenildae (16.4\%) were recovered. A. fraterculus was by far the most frequent species in all collections in this region. Our findings corroborate previous studies that show this species was also the most frequently recovered from systematic collections of guavas during the period of one to five years (SOUZA-FILHO et al., 2007; SILVA et al. 2010) as well as from traps (DUTRA et al., 2009). In the southern region, guava was also infested by three Anastrepha species, A. fraterculus, A. sororcula, and A. zenildae, while Surinam cherry was infested by A. fraterculus and $A$. sororcula. In a previous study, Souza-Filho et al. (2007) also reported A. fraterculus, A. sororcula, and $A$. zenildae infesting guava in one area in the municipality of Una. Silva et al. (2010) recovered A. fraterculus, A. obliqua, A. sororcula, and $A$. zenildae from guava in three areas also in the municipality of Una. In one of the collections in southern Bahia, A. zenildae was found infesting Malay apple for the first time in Brazil (Table 1).

In the central-southern region $A$. fraterculus $(68.8 \%)$, A. zenildae (6.2\%), and A. sororcula $(25 \%)$ were recovered from collected guava fruit. This is the first record of fruit fly and myrtaceous host associations in the central-southern region of Bahia. Previous studies carried out in this region in the municipalities of Livramento de Nossa Senhora and Manoel Vitorino had focused on trapping or collection of Anacardiaceae fruit (NASCIMENTO; CARVALHO, 2000; SILVA et al., 2008). Nascimento and Carvalho (2000) reported a very high frequency of C. capitata $(99.39 \%)$ in Livramento de Nossa Senhora. They indicated that this result was likely due to the presence of extensive mango groves and to the local climatic conditions. Silva et al. (2008) collected umbu fruit (Spondias tuberosa Arr. Cam.) in the municipality of Manoel Vitorino, and the only fruit fly species recovered was $A$. obliqua.

In the central-northern region, the only fruit fly species recovered was C. capitata $(100 \%)$ from both guava and Brazilian guava. In the northern region, A. sororcula (53.3\%) and A. zenildae (46.7\%) were recovered from fruit. In the western region, only A. zenildae (100\%) was found infesting guava. We should be cautious in extrapolating the data from the fruit collected there to the entire western region, since our sampling was limited. These last three regions are all located in the semiarid of Bahia which is characterized by very low annual average rainfall (SEI, 2002). In a survey using McPhail traps in the area of the São Francisco sub-Middle Valley in the northern region of Bahia (Juazeiro - BA and Petrolina - PE), Nascimento and Carvalho (2000) reported the occurrence of A. obliqua, A. pickeli, Anastrepha dissimilis Stone, and $A$. sororcula in rural areas and C. capitata in urban areas. The presence of $A$. zenildae in Petrolina, state of Pernambuco, was reported by Haji \& Miranda (2000). It is noteworthy that $A$. sororcula and/or $A$. zenildae were the dominant species recovered from guava collected in orchards in semiarid regions in the states of Minas Gerais and Rio Grande do Norte (ALVARENGA et al., 2009; ARAUJO et al., 2005). A pattern of species dominance is observed in the Brazilian Northeast, where A. fraterculus predominates in more humid regions while $A$. zenildae and $A$. sororcula predominate in the more arid regions. These latter two species appear to be better adapted than A. fraterculus to dry climates (MALAVASI et al., 2000).

The highest fruit fly infestation rates were observed in the samples from the southern region, where all reported myrtaceous fruit fly hosts were collected. The hosts E. uniflora and P. guajava were the preferred hosts of tephritids, with maximum rates of 306.7 pupae $/ \mathrm{Kg}$ and 197.6 pupae/Kg, respectively (Table 1). These rates were higher than those reported by Malavasi et al. (1980) in different locations in Brazil.

Guava was the preferred host for A. fraterculus in Bahia. As well, guava was the myrtaceous species that hosted the highest diversity of fruit flies. These results corroborate results from several studies in other states in Brazil (MALAVASI et al., 1980; SILVA et al., 1996; SOUZA FILHO et al., 2009).

Interestingly, C. capitata was found only infesting fruit that were collected in urban areas, whereas Anastrepha spp. were found both in rural and urban areas. Similar results were reported in other regions in Brazil and Argentina by Malavasi et al. (2000) and Ovruski et al. (2003), respectively. The latter authors concluded that $C$. capitata seems 
to adapt well to environments that have been highly disturbed.

Regarding parasitoids, three species were recovered Doryctobracon areolatus (Szépligeti) (79.8\%), Utetes anastrephae (Viereck) (19\%), and Asobara anastrephae (Muesebeck) (1.2\%) (Hymenoptera: Braconidae). All parasitoids were recovered only from Anastrepha species. D. areolatus was by far the most predominant parasitoid species (Table 2). Previous studies similarly found $D$. areolatus to be the most predominant fruit fly parasitoid in southern Bahia (SOUZA-FILHO et al., 2007; SILVA et al., 2010) and in the Recôncavo region (CARVALHO, 2005 ) as well as throughout Brazil (ARAUJO; ZUCCHI, 2002; UCHÔA-FERNANDES et al., 2003).

The highest level of parasitism was detected in Anastrepha larvae/puparia recovered from Surinam cherry (51.0\%). From these parasitized larvae/ puparia emerged the three parasitoid species, $D$. areolatus $(81.6 \%)$, U. anastrephae $(16.3 \%)$, and A. anastrephae $(2.1 \%)$. High parasitism rates in Surinam cherry in Brazil have been reported by other authors (AGUIAR-MENEZES; MENEZES, 1997; HICKEL, 2002). High parasitism in Surinam cherry is probably due to the small fruit size and fine exocarp since parasitoids may thus more easily locate larvae in the fruit endocarp. This higher frequency of D. areolatus in Surinam cherry may be explained by the ability of the parasitoid to parasitize fruit fly larvae in different stages in the fruit. This characteristic may render $D$. areolatus more competitive when compared to the other two recovered parasitoid species.

In this study, we report previously undocumented fruit fly and myrtaceous fruit associations and parasitoids in several municipalities in the state of Bahia (Table 1). Of the four fruit fly species that were reared from the collected fruit, A. fraterculus had the highest species frequency in areas with more humid climatic conditions whereas $C$. capitata, $A$. zenildae, and $A$. sororcula showed higher frequency in the semiarid region. Our results further confirm guava as the preferred host for $A$. fraterculus wherever both/ either are found throughout Brazil.

TABLE 1 - Anastrepha species and braconids reared from myrtaceous collected in the state of Bahia, Brazil.

\begin{tabular}{|c|c|c|c|c|c|c|c|c|}
\hline Region & Municipality & Host plant species & $\begin{array}{c}\mathrm{N}^{0} \text { of } \\
\text { fruit } \\
\text { sampled }\end{array}$ & $\begin{array}{l}\text { Kg of } \\
\text { fruit }\end{array}$ & $\begin{array}{c}\text { Total } \\
\mathbf{n}^{0} \text { of } \\
\text { pupae }\end{array}$ & $\begin{array}{c}\mathrm{N}^{\circ} \text { of } \\
\text { pupae/Kg } \\
\text { of fruit }\end{array}$ & $\begin{array}{c}N^{\circ} \text { of Adults } \\
\text { (Males / } \\
\text { Females) }\end{array}$ & Fruit fly species \\
\hline North & Juazeiro & P. guajava (guava) & 56 & 4.30 & 51 & 11.9 & $20 / 15$ & $\begin{array}{l}8 \mathrm{~A} . \text { sororcula } \\
7 \mathrm{~A} . \text { zenildae }\end{array}$ \\
\hline \multirow{3}{*}{$\begin{array}{l}\text { Central- } \\
\text { West }\end{array}$} & Itaberaba & P. guajava (guava) & 57 & 4.60 & 85 & 18.5 & $41 / 36$ & 36 C. capitata \\
\hline & \multirow{2}{*}{ Jacobina* } & P. guajava (guava) & 9 & 1.00 & 33 & 33.0 & $11 / 10$ & 10 C. capitata \\
\hline & & $\begin{array}{c}P . \text { guineense } \\
\text { (Brazilian guava) }\end{array}$ & 24 & 0.68 & 24 & 35.3 & $4 / 7$ & 7 C. capitata \\
\hline West & Barreiras* & P. guajava (guava) & 25 & 2.30 & 15 & 6.5 & $0 / 2$ & 2 A. zenildae \\
\hline \multirow{5}{*}{$\begin{array}{l}\text { Central- } \\
\text { South }\end{array}$} & Itapetinga* & P. guajava (guava) & 2 & 0.40 & 2 & 5.0 & $0 / 2$ & $\begin{array}{l}1 \mathrm{~A} . \text { fraterculus } \\
1 \mathrm{~A} . \text { zenildae }\end{array}$ \\
\hline & Itiruçu * & P. guajava (guava) & 10 & 2.05 & 29 & 14.1 & $10 / 4$ & 4 A. fraterculus \\
\hline & Jitaúna $*$ & P. guajava (guava) & 95 & 7.30 & 90 & 12.3 & $16 / 16$ & 16 A. fraterculus \\
\hline & Milagres * & P. guajava (guava) & 13 & 0.65 & 15 & 23.1 & $7 / 8$ & 8 A. sororcula \\
\hline & Ubaíra * & P. guajava (guava) & 9 & 0.75 & 7 & 9.3 & $1 / 2$ & $\begin{array}{l}1 \mathrm{~A} . \text { fraterculus } \\
1 \mathrm{~A} . \text { zenildae }\end{array}$ \\
\hline
\end{tabular}


$\begin{array}{llllllll}\text { Camamu } & \text { P. guajava (guava) } & 6 & 1.50 & 108 & 72.0 & 12 / 27 & 7 \text { A. } \text {. soratercula }\end{array}$

3 A. zenildae

\begin{tabular}{|c|c|c|c|c|c|c|c|c|}
\hline \multirow[t]{4}{*}{ Recôncavo } & Taperoá & P. guajava (guava) & 4 & 1.20 & 45 & 37.5 & $13 / 12$ & $\begin{array}{l}8 \text { A. fraterculus } \\
1 \text { A. sororcula } \\
3 \text { A. zenildae }\end{array}$ \\
\hline & & $\begin{array}{c}\text { E. uniflora } \\
\text { (Surinam cherry) }\end{array}$ & 64 & 0.50 & 17 & 34.0 & $3 / 1$ & 1 A. fraterculus \\
\hline & Valença & $\begin{array}{c}\text { M. cauliflora } \\
\text { (jaboticaba) }\end{array}$ & 26 & 1.00 & 3 & 3.0 & $2 / 1$ & 1 A. fraterculus $* *$ \\
\hline & & P. guajava (guava) & 10 & 1.60 & 20 & 12.5 & $14 / 4$ & 4 A. fraterculus \\
\hline \multirow{17}{*}{ South } & Barrolândia & $\begin{array}{c}\text { E. uniflora } \\
\text { (Surinam cherry) }\end{array}$ & 50 & 0.70 & 34 & 48.6 & $20 / 8$ & $\begin{array}{l}2 \text { A. fraterculus } \\
6 \text { A. sororcula } \\
\end{array}$ \\
\hline & Gandu* & P. guajava (guava) & 14 & 1.50 & 49 & 32.7 & $11 / 15$ & $\begin{array}{l}13 \text { A. fraterculus } \\
2 \text { A. sororcula }\end{array}$ \\
\hline & Ibirataia* & P. guajava (guava) & 50 & 2.80 & 60 & 21.4 & $11 / 18$ & $\begin{array}{l}16 \text { A. fraterculus } \\
1 \text { A. sororcula } \\
1 \mathrm{~A} \text {. zenildae }\end{array}$ \\
\hline & Ilhéus & P. guajava (guava) & 14 & 1.70 & 32 & 18.8 & $15 / 17$ & 17 A. fraterculus \\
\hline & Ipiaú* & P. guajava (guava) & 14 & 0.95 & 43 & 45.3 & $14 / 14$ & $\begin{array}{l}12 \text { A. fraterculus } \\
2 \text { A. sororcula }\end{array}$ \\
\hline & Itabuna & P. guajava (guava) & 12 & 1.00 & 93 & 93.0 & $9 / 18$ & $\begin{array}{l}5 \text { A. fraterculus } \\
13 \text { A. zenildae }\end{array}$ \\
\hline & Itacaré* & P. guajava (guava) & 1 & 0.15 & 15 & 100.0 & $8 / 5$ & 5 A. fraterculus \\
\hline & Itapé* & P. guajava (guava) & 34 & 2.85 & 350 & 122.8 & $165 / 160$ & $\begin{array}{l}89 \text { A. fraterculus } \\
13 \text { A. sororcula } \\
58 \text { A. zenildae }\end{array}$ \\
\hline & Nova Ibiá* & P. guajava (guava) & 15 & 1.65 & 40 & 24.2 & $15 / 12$ & 12 A. fraterculus \\
\hline & Porto Seguro & $\begin{array}{l}\text { S. malaccense } \\
\text { (Malay apple) }\end{array}$ & 10 & 2.30 & 32 & 10.0 & $10 / 12$ & 12 A. fraterculus \\
\hline & & P. guajava (guava) & 12 & 1.50 & 15 & 13.9 & $7 / 7$ & 7 A. fraterculus \\
\hline & \multirow{4}{*}{ Una } & $\begin{array}{c}\text { E. uniflora } \\
\text { (Surinam cherry) }\end{array}$ & 130 & 0.75 & 230 & 306.7 & $8 / 11$ & 11 A. fraterculus \\
\hline & & P. guajava (guava) & 22 & 2.50 & 494 & 197.6 & $164 / 158$ & $\begin{array}{c}150 \mathrm{~A} \text {. fraterculus } \\
5 \mathrm{~A} . \text { sororcula } \\
3 \mathrm{~A} . \text { zenildae } \\
\end{array}$ \\
\hline & & $\begin{array}{c}\text { P. guineense } \\
\text { (Brazilian guava) }\end{array}$ & 13 & 0.50 & 20 & 40.0 & $4 / 11$ & 11 A. fraterculus \\
\hline & & $\begin{array}{l}\text { S. malaccense } \\
\text { (Malay apple) }\end{array}$ & 50 & 4.60 & 60 & 13.0 & $9 / 10$ & $\begin{array}{l}6 \text { A. fraterculus } \\
4 \text { A. zenildae ** }\end{array}$ \\
\hline & $\begin{array}{c}\text { Wenceslau } \\
\text { Guimarães* }\end{array}$ & P. guajava (guava) & 6 & 0.40 & 23 & 57.5 & $4 / 7$ & 7 A fraterculus \\
\hline & Total & & 857 & 55.68 & 2,134 & & $628 / 630$ & \\
\hline
\end{tabular}

* First report of fruit flies infesting fruit in this municipality. ** First report of this fruit fly and host plant association. 
TABLE 2 - Host plant/ fruit fly/parasitoid associations and parasitism rates in myrtaceous collected in different municipalities in Bahia, Brazil.

\begin{tabular}{|c|c|c|c|c|}
\hline Municipalities & Host plant species & Fruit fly species & Parasitoids & Parasitism rate $(\%)$ \\
\hline Barrolândia & E. uniflora & $\begin{array}{l}6 \mathrm{~A} \text {. sororcula } \\
2 \mathrm{~A} \text {. fraterculus }\end{array}$ & 6 D. areolatus & 21.4 \\
\hline Itabuna & P. guajava & $\begin{array}{l}13 \text { A. zenildae } \\
5 \text { A. fraterculus }\end{array}$ & 3 D. areolatus & 10.0 \\
\hline Itapé & P. guajava & $\begin{array}{l}89 \text { A. fraterculus } \\
58 \text { A. zenildae } \\
13 \text { A. sororcula }\end{array}$ & $\begin{array}{l}5 \mathrm{U} . \text { anastrephae } \\
4 \mathrm{D} \text {. areolatus }\end{array}$ & 2.7 \\
\hline Nova Ibiá & P. guajava & 12 A. fraterculus & 5 D. areolatus & 15.6 \\
\hline \multirow[t]{3}{*}{ Una } & E. uniflora & 11 A. fraterculus & $\begin{array}{l}34 \text { D. areolatus } \\
8 \text { U. anastrephae } \\
1 \text { A. anastraphae }\end{array}$ & 69.3 \\
\hline & P. guineense & 11 A. fraterculus & 1 D. areolatus & 6.25 \\
\hline & S. malaccense & 6 A. fraterculus & 14 D. areolatus & 47.2 \\
\hline
\end{tabular}

4 A. zenildae 3 U. anastrephae 502,2008.

\section{ACKNOWLEDGMENTS}

We are grateful to André M. Amorim for his help with plant identification. We would also like to thank Carter R. Miller and an anonymous reviewer for their helpful comments on the manuscript. This study was funded by FAPESB (Fundação de Amparo à Pesquisa no Estado da Bahia, grant $n^{\circ}$ 0027/2006) and Universidade Estadual de Santa Cruz (Proc. 00220.1100.289 and 00220.1100.552). LNS was supported by a FAPESB fellowship during her MSc.

\section{REFERENCES}

AGUIAR-MENEZES, E.L.; MENEZES, E.B. Natural occurrence of parasitoids of Anastrepha spp. Schiner, 1868 (Diptera: Tephritidae) in different host plants, in Itaguai (RJ), Brazil. Biological Control, Netherlands, v.8, p.1-6, 1997.

ALUJA, M.; MANGAN, R.L. Fruit fly (Diptera: Tephritidae) host status determination: critical conceptual, methodological, and regulatory considerations. Annual Review of Entomology, Oxford, v.53, p.473-
ALVARENGA, C.D.; MATRANGOLO, C.A.R.; LOPES, G.N.; SILVA, M.A.; LOPES, E.N.; ALVES, D.A.; NASCIMENTO, A.S.; ZUCCHI, R.A. Moscasdas-frutas (Diptera: Tephritidae) e seus parasitoides em plantas hospedeiras de três municípios do norte do Estado de Minas Gerais. Arquivos do Instituto Biológico, São Paulo, v.76, p.195-204, 2009.

ARAUJO, E.L.; MEDEIROS, M.K.M.; SILVA, V.E.; ZUCCHI, R.A. Moscas-das-frutas (Diptera: Tephritidae) no semiárido do Rio Grande do Norte: plantas hospedeiras e índices de infestação, Neotropical Entomology, Piracicaba, v.34, p.889-894, 2005.

ARAUJO, E.L.; ZUCCHI, R.A. Medidas do acúleo na caracterização de cinco espécies de Anastrepha do grupo fraterculus (Diptera: Tephritidae). Neotropical Entomology, Piracicaba, v.35, p.1-9, 2006.

ARAUJO, E.L.; ZUCCHI, R.A. Parasitoides (Hymenoptera: Braconidae) de moscas-das-frutas (Diptera: Tephritidae) na região de Mossoró/Assu, Estado do 
Rio Grande do Norte. Arquivos do Instituto Biológico, São Paulo, v.69, p.65-68, 2002.

CANAL, N.A.; ZUCCHI, R.A. Parasitoides - Braconidae. In: MALAVASI, A.; ZUCCHI, R.A. Moscasdas-frutas de importância econômica no Brasil: conhecimento básico e aplicado. Ribeirão Preto: Holos, 2000. p.119-126.

CARVALHO, R.S. Avaliação das liberações inundativas do parasitoide exótico Diachasmimorpha longicaudata (Ashmead) (Hymenoptera: Braconidae) em pomar diversificado em Conceição do Almeida, BA. Neotropical Entomology, Piracicaba, v.34, p.799-805, 2005.

DUTRA, V.S.; SANTOS, M.S.; SOUZA-FILHO, Z.A.; ARAUJO, E.L.; SILVA, J.G. Análise faunística de Anastrepha spp. (Diptera: Tephritidae) em um pomar de goiaba sob manejo orgânico, no município de Una, BA. Neotropical Entomology, Piracicaba, v.38, p.133-138, 2009.

GRESSLER, E.; PIZO, M.A.; MORELLATO, P.C. Polinização e dispersão de sementes em Myrtaceae do Brasil. Revista Brasileira de Botânica, São Paulo, v.29, p.509-530, 2006.

HAJI, F.N.P.; MIRANDA, I.G. Moscas-das-frutas nos Estados Brasileiros: Pernambuco. In: MALAVASI, A.; ZUCCHI, R.A. Moscas-das-frutas de importância econômica no Brasil: conhecimento básico e aplicado. Ribeirão Preto: Holos, 2000. p.229-233.

HICKEL, E.R. Espessura da polpa como condicionante do parasitismo de moscas-das-frutas (Diptera: Tephritidae) por Hymenoptera: Braconidae. Ciência Rural, Santa Maria, v.32, p.1005-1009, 2002.

IBRAF. Instituto Brasileiro de Frutas. Soluções fruta a fruta. São Paulo. 2007. Disponível em: $<$ http:// www.ibraf.com.br>. Acesso em: 02 maio 2010.

LIMA, M.A.C.; BASSOL, L.H.; SILVA, D.J.; SANTOS, P.S.; PAES, P.C.; RIBEIRO, P.R.A.; DANTAS, B.F. Effects of levels of nitrogen and potassium on yield and fruit maturation of irrigated guava trees in the São Francisco Valley. Revista Brasileira de Fruticultura, Jaboticabal ,v.30, p.246-250, 2008.

MALAVASI, A.; MORGANTE, J.S.; ZUCCHI, R.A. Biologia de "Moscas-das-frutas" (Diptera: Tephritidae). I: Lista de Hospedeiros e Ocorrência. Revista Brasileira de Biologia, São Carlos, v.40, p.9-16, 1980.

MALAVASI,A.; ZUCCHI, R.A.; SUGAYAMA, R.L. Biogeografia. In: MALAVASI, A.; ZUCCHI, R.A. Moscas-das-frutas de importância econômica no Brasil: conhecimento básico e aplicado. Ribeirão Preto: Holos, 2000. p.93-98.

MAPA. Ministério da Agricultura, Pecuária e Abastecimento. Anuário brasileiro da fruticultura. Santa Cruz do Sul, 2002. 176p.

NASCIMENTO, A.S.; CARVALHO, R.S. Moscasdas-frutas nos Estados Brasileiros: Bahia. In: MALAVASI, A.; ZUCCHI, R.A. Moscas-das-frutas de importância econômica no Brasil: conhecimento básico e aplicado. Ribeirão Preto: Holos, 2000. p.235-239.

NASCIMENTO, A.S.; CARVALHO, R.S.; MALAVASI, A. Monitoramento populacional. In: MALAVASI, A.; ZUCCHI, R.A. Moscas-das-frutas de importância econômica no Brasil: conhecimento básico e aplicado. Ribeirão Preto: Holos, 2000. p.109-112.

NASCIMENTO, A.S.; ZUCCHI, R.A. Dinâmica populacional das moscas-das-frutas do gênero Anastrepha (Dip., Tephritidae) no Recôncavo Baiano, ILevantamento das espécies. Pesquisa Agropecuária Brasileira, Brasília, v.16, p.763-767, 1981.

OVRUSKI, S.; SCHLISERMAN, P.; ALUJA, M. Native and introduced host plants of Anastrepha fraterculus and Ceratitis capitata (Diptera: Tephritidae) in Northwestern Argentina. Annals of the Entomological Society of America, Lanham, v.96, p.1108-1118, 2003.

RAGA, A.; SOUZA FILHO, M.F.; PRESTES, D.A.O.; AZEVEDO FILHO, J.A.; SATO, M.E. Susceptibility of guava genotypes to natural infestation by Anastrepha spp. (Diptera: Tephritidae) in the municipality of Monte Alegre do Sul, state of São Paulo, Brazil. Neotropical Entomology, Piracicaba, v.35, p.121-125, 2006.

SEI. Superintendência de Estudos Econômicos e Sociais da Bahia. Estatísticas dos Municípios Baianos. Secretaria de Planejamento e Ciência Tecnológica, Salvador, v.2, n.1, 2002. CD-ROM.

SILVA, J.G.; DUTRA, V.S.; SANTOS, M.S.; SILVA, N.M.O.; VIDAL, D.B.; NINK, R.A.; GUIMARÃES, J.A.; ARAUJO, E.L. Diversity of Anastrepha spp. (Diptera: Tephritidae) and associated braconid parasitoids from native and exotic hosts in Southeastern 
Bahia, Brazil. Environmental Entomology, College Park, v. 39, p.1457-1465, 2010

SILVA, N.M.; SILVEIRA NETO, S.; ZUCCHI, R.A. The natural host plants of Anastrepha in the State of Amazonas, Brazil. In: MCPHERON, B.A.; STECK, G.J. Fruit fly pests: a world assessment of their biology and management. Delray Beach: St. Lucie Press, 1996. p.353-357.

SILVA, N.M.O.; CARDOSO, J.S.; DELABIE, J.H.C.; SILVA, J.G. Fruit flies (Diptera: Tephritidae) associated with umbu (Spondias tuberosa Arr. Cam.) in the semiarid region of Bahia, Brazil. Florida Entomologist, Lutz, v.91, p.709-710, 2008.

SOUZA-FILHO, M.F.; RAGA, A.; AZEVEDO FILHO, J.A.; STRIKIS, P.C.; GUIMARÃES, J.A.; ZUCCHI, R.A. Diversity and seasonality of fruit flies (Diptera: Tephritidae and Lonchaeidae) and their parasitoids (Hymenoptera: Braconidae and Figitidae) in orchards of guava, loquat and peach. Brazilian Journal of Biology, São Carlos, v.69, p.31-40, 2009.

SOUZA-FILHO, Z.A.; ARAUJO, E.L.; GUIMARÃES, J.A.; SILVA, J.G. Endemic parasitoids associated with Anastrepha spp. (Diptera: Tephritidae) infesting guava (Psidium guajava $\mathrm{L}$.) in southern
Bahia, Brazil. Florida Entomologist, Lutz, v.90, p.783-785, 2007.

UCHÔA-FERNANDES, M.A.; MOLINA, R.M.S.; OLIVEIRA, I.; ZUCCHI, R.A.; CANAL, N.A.; DÍAZ, N.B. Larval endoparasitoids (Hymenoptera) of frugivorous flies (Diptera, Tephritoidea) reared from fruits of the cerrado of the State of Mato Grosso do Sul, Brasil. Revista Brasileira de Biologia, São Carlos, v.47, p.181-186, 2003.

ZUCCHI, R.A. Diversidad, distribución y hospederos del género Anastrepha en Brasil. In: HERNÁNDEZORTIZ, V. Moscas de la Fruta en Latinoamérica (Diptera: Tephritidae): diversidad, biología y manejo. México: S y G Editores, 2007. p.77-100.

ZUCCHI, R.A.Taxonomia. In: MALAVASI, A.; ZUCCHI, R.A. Moscas-das-frutas de importância econômica no Brasil: conhecimento básico e aplicado. Ribeirão Preto: Holos, 2000. p.13-24. 